DOI $10.31168 / 2619-0869.2018 .2 .3 .3$

Я.А. Пенькова

\title{
К типологии
}

нефутуральных значений предбудущего в славянских языках*

Темпоральная парадигма славянского перфекта, сформировавшаяся в праславянском языке на основе фрорм вспомогательного byti и $l$-причастия (РТСР), включала в себя перфрект, плюсквамперфект и предбудущее $b o d q+l$-РТСР (конструкция, объединяющая показатели редеренции к будущему и предшествования). Семантика славянского перфректа и плюсквамперфекта достаточно хорошо изучена. Славянское предбудущее как довольно редкая конструкция всегда вызывала существенно меньшее внимание исследователей ${ }^{1}$, а ее значение обычно считалось чисто композициональным.

Как известно, перфект в истории славянских языков эволюционирует в соответствии с двумя «сценариями» ${ }^{2}:$ проходя через стадию «расширенного перфекта», превращается в простой претерит (например, в восточнославянских языках) или специализируется на выражении эвиденциальных значений (в болгарском и македонском). По мере эволюции презентного перфекта семантическое противопоставление между ним и плюсквамперфектом «все более усложняется и идиоматизируется, приводя... к их включению в разные семантические зоны» ${ }^{3}$ (плюсквамперфект развивает значения из семантической зоны «сверхпрошлого» и ирреалиса ${ }^{4}$ ).

Аналогичное семантическое расхождение можно наблюдать и между перфектом и предбудущим (футуральным перфектом). Настоящая работа посвящена данной проблематике - типологии недутуральных значений предбудущего (употреблений с референцией к прошлому) в славянских

* Работа выполнена при поддержке гранта РФФИ (РГНФ), проект № 17-3401061 «Славянское второе будущее в типологической перспективе». 
языках. Иллюстрацией того, что понимается под нефутуральными употреблениями, может служить пример из Супрасльской рукописи:

(1) старосл. Еда бждетъ сълъгалъ приходивыи, почто ми гнъвити Азыкъ старцу? ${ }^{5}$

Спектр недутуральных употреблений предбудущего довольно широк: презумптивные, конклюзивные, дубитативные и близкие к ним адмиративные употребления, кроме того, передача внутреннего опыта говорящего, а также аппрехенсивные употребления. Будем называть их модально-эвиденциальными стратегиями, вслед за А. Айхенвальд 6 , предложившей подобный термин для языковых средств, чьей первичной функцией не является указание на то или иное эвиденциальное значение.

Праславянская перифраза $b q d q+l$-PТСР имела различную судьбу в истории славянских языков ${ }^{7}$. Грамматикализованное предбудущее сохранилось только в глагольных системах южнославянских языков (македонский в работе не рассматривается), при этом структура, восходящая к праславянской перифрразе $b q d q+l$-РТСР, представлена только в сербохорватском, тогда как болгарский и македонский

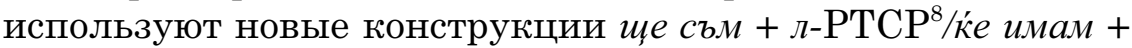
н-РТСР. В современных сербохорватских говорах (по крайней мере в средне- и южночакавских и части штокавских) также употребительна конструкция бићy + l-PТСР - форма предбудущего с другим вспомогательным глаголом.

Ввиду ограничений объема мы будем приводить примеры в основном из современного болгарского и сербохорватского. Отсутствие специального комментария означает фиксацию подобных употреблений также в древнерусских и средневековых болгарских источниках.

1.1. Для славянского предбудущего наиболее типичны презумптивные (1-2) и конклюзивные (3-4) стратегии (в сербохорватском - только для перифразы бићy + l-PТСР). Среди славянских языков с древней письменностью, имеющих перифразу предбудущего, такие употребления отсутствуют в древнечешском, средневековых сербских и хорват- 
ских памятниках. Возможно, такое распределение явилось следствием позднепраславянских диалектных различий ${ }^{9}$, ср.:

(2) болг. Казахме, че никой не ни е казвал това, но че някак инстинктивно сме се досетили, че тъкмо той щце е свършил тая работа ${ }^{10}$;

(3) болг. И-гробове, гробове. Тук щее са се били туричи, защуото на повечето гробове... беше забита тояга ${ }^{11}$;

(4) чакав. Bićete se umorili? ${ }^{12}$

1.2. В презумптивном или конклюзивном значении сербохорватский футур други не употребляется, однако в вопросительных предложениях с да может сочетать выражение догадки с выражением опасения ${ }^{13}$ :

(5) сербохорв. Да не будеш то забравио код куће? ${ }^{14}$

Подобные аппрехенсивные употребления предбудущего в литературном сербохорватском (и единичные примеры в болгарских памятниках XVII в.) мы предлагаем считать особой интерпретацией презумптивных, поскольку именно значение эпистемической модальности (оценка ситуации как вероятной, возможной) типологически признается одним из семантических источников аппрехенсива ${ }^{15}$.

2. Предбудущим могут обозначаться ситуации прямого личного доступа, но, по-видимому, только те, которые сообщают о внутреннем ментальном или фризическом опыте говорящего (чувства, ощущения, фозическое состояние, когнитивные процессы) - т. е. о том, что принципиально не может быть наблюдаемым. Для болгарского предбудущего такие контексты нехарактерны, в отличие от сербохорватского с неизменяемым biče, ср.:

(6) чакав. Biče do ure po ponoč san sedila ${ }^{16}$.

3. Напротив, предбудущее в болгарском, в отличие от сербохорватского, встречается в дубитативных контекстах. Такая интерпретация возникает обычно при некоторых дополнительных контекстных условиях: при ироничном пересказывании чужих слов для дистанщирования от чужого мнения, которое говорящий не разделяет. Дубитативные значения могут выражаться кумулятивно с адмиративными 
(последние в чистом виде у славянского предбудущего практически не представлены):

(7) болг. „Окраде Русия“-казват. Как така мее е окрал Русия? От хазната ли взема пари? ${ }^{17}$

\section{Выводы}

При всем разнообразии перечисленных стратегий (адмиратив и аппрехенсив не принадлежат семантической зоне эвиденциальности), у них есть общие семантические основания: предбудущее в них используется для выражения эпистелической дистаниии (термин, употребляемый В.А. Плунгяном, а также Г. Лантом и М.М. Макарцевым - по отношению к балканским эвиденщиалам $\left.{ }^{18}\right)$. Дистанция при презумптивных и конклюзивных употреблениях основана на неточном знании говорящего (отсутствии прямого доступа), при передаче внутреннего опыта - на ненаблюдаемости явления, при дубитативных употреблениях - на дистанщировании от чужого мнения, при адмиративных - на противоречии картине мира говорящего, при аппрехенсивных - на нежелательности ситуации для говорящего. Предбудущее в нефртуральных употреблениях в болгарском семантически и структурно вписывается в систему эвиденциалов, имеющих в составе л-фрорму.

\section{тримечания}

${ }^{1}$ См. обзор библиографии: Пенькова Я.А. К вопросу о семантике т.н. будущего сложного II в древнерусском языке (на материале «Жития Андрея Юродивого») // Русский язык в научном освещении 2014. № 1 (27). С. 150-184; Пенькова Я.А. К истории славянского второго будущего: пути семантической эволюции // Die Welt der Slaven, 2017. № 2 (62). С. 247-275.

2 Плунгян B.A. К типологии перфекта в языках мира // Труды Института лингвистических исследований РАН - Acta Linguistica Petropolitana 2016. Т. 12. № 2. С. 7-36.

3 Там же.

4 Сичинава Д.В. Типология плюсквамперфекта. Славянский плюсквамперфект. M., 2013.

5 Заимов Й., Капалдо М. Супраслъски или ретков сборник. София, 1982. Т. І-ІІ. C. 239.

6 Aikhenvald A. Evidentiality. Oxford, 2004.

7 Подробнее о грамматикализации предбудущего в славянских языках см.: Пенькова Я.А. От ретроспективности к проспективности: грамматикализация предбудущего в языках Европы // Вопросы языкознания. 2018. № 2. С. 53-70. 
8 С типологической точки зрения в болгарском логично выделять не две омонимичные формы ще съм + л-PTCP: выражающую таксисные значения (будущее предварительное), с одной стороны, и значения эпистемической модальности (тпрезумптив), с другой, а одну семантически многозначную, так как тот же семантический спектр у предбудущего встречается во многих других европейских языках, в том числе и в албанском.

9 См. также: Andersen H. Periphrastic futures in Slavic: Divergence and convergence // Change in verbal systems. Issues in explanation. Eksell K., Vinther T. (eds.). Bern, 2006. C. 9-45.

10 Asen Hristoforov Dzherom K. Dzherom Trima dushi v edna lodka (bez da stava duma za kucheto). Национальный корпус болгарского языка: URL: http://search. dcl.bas.bg/ (дата обращения: 08.04.2018).

11 (Й. Йовков) Деянова М. Към характеристиката на новобългарското бъдеще предварително време // Пашов П., Ницолова Р. Помагало по българска морфология. Глагол. София, 1976.

12 Пример сообщен Миславом Беничем.

13 Коваћевић М. Употреба футура II у простој реченици // Српски језик - студије српске и словенске. 2009. № 14. 1-2. С. 65-75.

14 Стевановић М. Савремени српскохрватски језик. Т. ІІ. Београд, 1986. С. 683. 15 Добрушина Н.P. Грамматические формы и конструкции со значением опасения и предостережения // Вопросы языкознания. 2006. № 2. С. 28-67.

16 Пример сообщен М. Беничем.

17 (Александър Литвиненко. Лубянската престъпна групировка (Здравка Петрова, 2003)) Национальный корпус русского языка: URL: http://ruscorpora.ru (дата обращения: 08.04.2018).

18 Макарцев М.М. Эвиденциальность в пространстве балканского текста. СПб., 2013.

DOI 10.31168/2619-0869.2018.2.3.4 Е. О. Борисова

\section{O семантической структуре гнезда рус. строгий (русские диалектные значения на славянском фонне)*}

На территории Архангельской области фриксируется прилагательное строгий 'быстрый, стремительный (о ручье)' Весенний ручей строгий был, с шумом, бурный. Необычность

* Исследование выполнено при поддержке гранта РНФ «Контактные и генетические связи севернорусской лексики и ономастики» (проект 17-18-01351). 